\title{
Analysis of energy potential of biofuels obtained from camelina sativa
}

\author{
Madalina Ghilvacs ${ }^{1}$, Razvan Carlanescu ${ }^{2, *}$, Maria Paraschiv $^{1}$, and Malina Prisecaru ${ }^{1}$ \\ ${ }^{1}$ Politehnica University of Bucharest, Faculty of Mechanical and Mechatronics Engineering, Splaiul \\ Independenței 313, Bucharest 060042, Romania \\ ${ }^{2}$ Romanian Research and Development Institute for Gas Turbines COMOTI, 220 D Iuliu Maniu Bd., \\ sector 6, Bucharest, Romania
}

\begin{abstract}
In a world where the energy demand is increasing daily, energy efficiency and renewable energy play a major role. Our research comes to help fighting the biggest problem that our world is facing today, global warming. This study aims to evaluate the energy potential of biofuels obtained from camelina sativa in order to reduce fossil fuel dependence, greenhouse gas emissions and increase energy efficiency. Camelina (Camelina sativa L.) is a cruciferous oilseed plant belonging to the Brassicaceae (mustard) family with the common name false flax and gold of pleasure. Since camelina can grow under different conditions without being a competitor of food land, this energetic plant can be used for production of both, first- and second-generation biofuels. In our study we determined the elemental analysis of the subproducts obtained from camelina sativa, through experimental tests, and we built a mathematical model to determine the calorific power and to simulate the burning of the biofuels into a steam generator in order to analyse the energy potential. The results show us that the biofuels obtained from camelina sativa can represent an alternative to fossil fuels and should be considered in the transition to green energy.
\end{abstract}

\section{Introduction}

According with the national energy strategy 2019-2030, with the prospect of the year 2050, beside energy efficiency, promoting energy from renewable sources plays an important role in order to reach the long-term global goal agreed at Paris in 2015, limiting the rise of the global average temperature to $2^{\circ} \mathrm{C}$, compared to the pre-industrial level. The total energy production based on biomass and waste presents, in all scenarios, a consistent increase during the analysed period, 2020-2050. The trend of accelerating biomass production after 2030 is notable, by developing modern and efficient technologies on a large scale, especially in the rural area.

For the period 2020 - 2050 - electricity production based on renewable sources (biomass) will be $0.9 \mathrm{TWh}(1.3 \%$ of the share of energy resources in electricity production)

\footnotetext{
* Corresponding author: razvan.carlanescu@,comoti.ro
} 
compared to $0.4 \mathrm{TWh}(0.7 \%$ of the share of energy resources in the production of electricity) in 2017. By 2030 small power stations powered exclusively with biomass, bioliquids, biogas, and waste will be developed, until such plants will have a total installed capacity of $139 \mathrm{MW}$. The boilers of some of the current thermoelectric power stations will be adapted to allow the burning of a biomass addition [1].

The promoting of energy from renewable sources will be done in particular for heating/cooling and transportation sector (biofuels). For heating/cooling sector, the goal is a rate of increase in the share of renewable energy sources in the total energy demand for heating and cooling by $1.3 \%$ annually by 2030 . Regarding transportation sector, the share of alternative fuels in the total energy demand for transport will increase from 5.4\% in 2015 to $12.8 \%$ in 2030 ; thus, a 2.5 -fold increase in the demand for biofuels is expected [1].

Renewed interest in camelina sativa is based on the interest of producing cost-effective biofuels [2]. Camelina sativa seeds have a high level of oil content, which is about $40 \%$ [3], can be grown as an annual summer or biannual winter crop under different climatic and soil conditions, can be grown on poorer soils and require lower inputs of fertilizers and pesticides than traditional crops which led to a substantial cost reduction [2] [4]. Many researchers have been evaluated the properties of biofuels obtained from camelina sativa and the possibility of using these biofuels in engines. The direct use of camelina sativa vegetable oil on a CI Perkins 1104C-44 engine was investigated in 2013. Results highlighted the fact that it's possible to obtain good engine performance when using camelina sativa vegetable oil, if some calibration parameters are adjusted [5]. There are several papers which investigated if the properties of bio-diesel obtained from camelina sativa oil are within the European standard for bio-Diesel limits [6] [7]. Studies on biokerosene production from camellia sativa oil have been also reported. Corporan E. et al. (2011) have reported that the bio-kerosen obtained from camelina sativa has better thermal oxidation stability than the classic aviation fuel, but to produce bio-kerosen from camellia sativa oil is still too expensive [8].

Through our work we would like to add a plus in promoting the using of biomass for both heating/cooling purpose and transportation sector. The first step in our work and this paper's focus is to evaluate the energy potential of camelina sativa subproducts. Our future work, which is already ongoing, will focus on obtaining biomass for second generation biofuels.

\section{Description of biomass}

Today's focus on engineering, genetic engineering, biology, chemistry, agricultural sciences is to find new energy sources, new methods of obtaining energy, more efficient biomass in order to replace the conventional fuels with biofuels.

Camelina, also known as lemongrass, yolk, egg yolk, fake, wild, German sesame, and Siberian sesame are a very old agricultural plant, cultivated for its oily seeds. The plant was cultivated in Europe before 1950 [9]. The main area of expansion was from Eastern Europe to Central Asia. Its cultivation area ranges from $36^{\circ}$ north latitude to $70^{\circ}$ north latitude. Today, camelina is grown in Romania, Slovenia, Ukraine, China, Finland, Germany, Austria and Montana in the US.

Camelina sativa was chosen for our research based on the following characteristics [10] [11] [12]: 
- Camelina can be grown in short marginal periods without being a competitor of food land since it can be used as a natural fertilizer when it is combined with edible crops on good arable land;

- Camelina possesses a short-season crop, (85-100 days);

- Camelina can be grown as an annual summer or biannual winter crop under different climatic and soil conditions;

- Camelina sativa can be grown on poorer soils and require lower inputs of fertilizers and pesticides than traditional crops;

- Camelina needs little water;

- Camelina sativa may be used as a rotation crop to improve the health of the soil.

The main product of Camelina sativa is the oil produced by crushing and pressing the seeds, the oil content of Camelina seeds ranged from 30 to $40 \%$. Extraction of oil from oilseeds by pressing yield a by-product called Oil cakes/meal.

The biofuel obtained from Camelina was used till now for two main purposes [13]:

- Camelina oil as feedstock for Renewable Jet Fuel;

- Camelina oil as feedstock for Renewable Biodiesel.

\section{Material and methods}

For this work, we used Camelia seeds, first Romanian camelina (Camelina sativa, L. Crantz) cultivar. The seeds, oil and meal (cake) for our experiments were provided by NARDI Fundulea. Camelia sativa seeds contain mainly, 4,25 - 5,24\% ash, 11,06-15,24\% cellulose, $18,87-21,97 \%$ proteins, $30,1-49,7 \%$ fats, and $25,83-28,21 \mathrm{mg} / 100 \mathrm{~g}$ vitamin E (gama tocopherol), as well as minerals - 0,18\% Calcium (Ca), 0,53\% Phosphorus (P), 0,49\% Cooper $(\mathrm{Cu}), 1,39 \%$ Manganese $(\mathrm{Mn}), 4,47 \%$ Iron $(\mathrm{Fe})$ and 2,56 $\%$ Zinc (Zn) [14].

The object of this research is to evaluate the potential of using camelina sativa subproducts (seeds, oil, meal) as replacements for fossil fuels in small power stations and to identify energy potential and pollutant emission variation when comparing with the ones of conventional fuels. A mathematical model was built in order to simulate the burning of camelina sativa subproducts in a small power station [15] [16] [17] [18] [19]. The mathematical model used for our research was built in MATLAB; the flow chart of the simulation is presented in figure 1 .

We used as entry data for our simulation the elemental analysis of camelina sativa subproducts, which we determined experimentally in a previous work [14]. The elemental analysis with reference to the initial state for Camelina oil, seeds and cake is presented in table 1.

For our experimental test we used THERMOSTAHL MCL-N boiler, $55 \mathrm{~kW}$. The boiler is made of steel, ideal material for thermal fluctuations, resistant to expansion and shrinkage. The monobloc construction, without elements and other welded structures is an advantage of the MCL-N boiler. This boiler is also protected against heat shock.

To determine the pollutant emissions, we used the method of discontinuous analysis on the $55 \mathrm{~kW}$ boilers using the AFRIXO MAXILYZER analyser - is a method of analysis with electrochemical cells. Throughout this method we determine the values of the pollutant emissions upon evacuation and due to the discontinuous character of the analysis a single value of the emissions representing an average value will be recorded. 


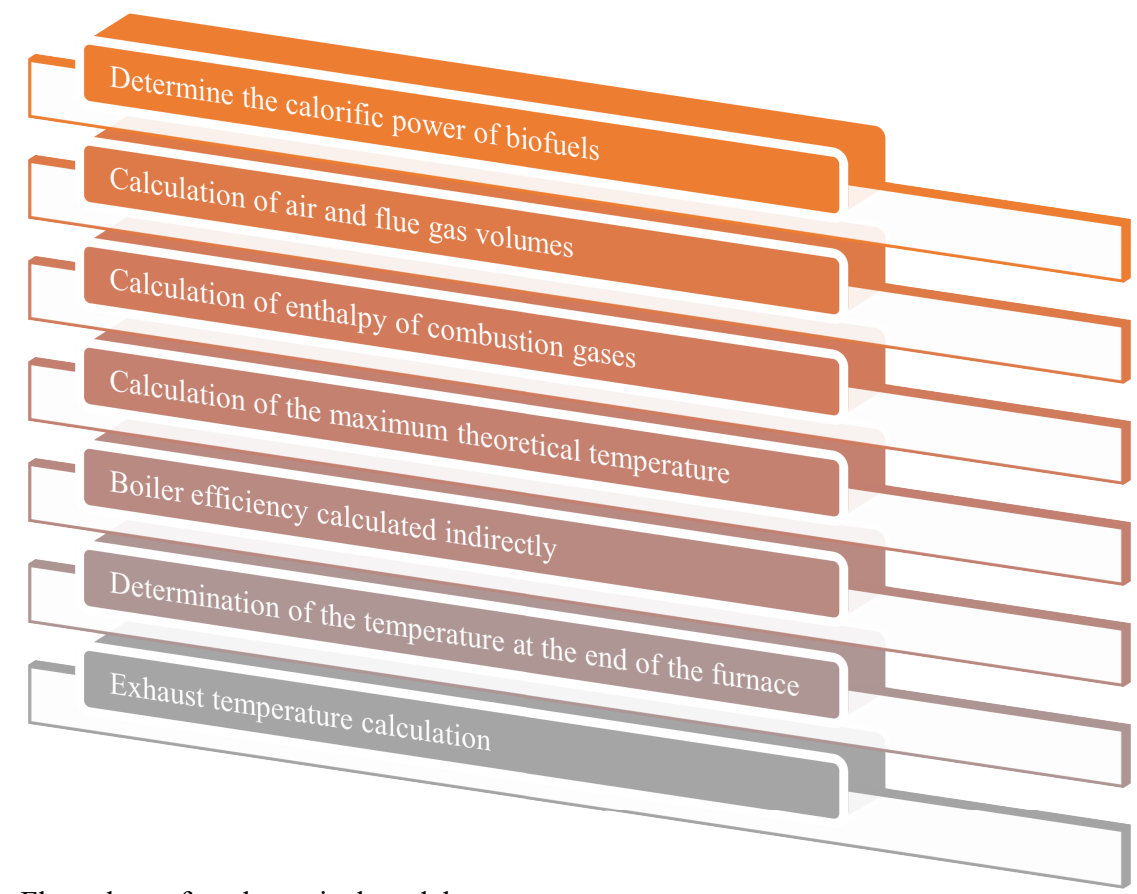

Fig. 1. Flow chart of mathematical model

Table 1. Elemental analysis of biofuels obtained from camelina sativa

\begin{tabular}{|c|c|c|c|c|c|c|c|}
\hline $\begin{array}{c}\text { Biomass } \\
\text { subproducts }\end{array}$ & $\begin{array}{c}\mathbf{C i} \\
{[\mathbf{\%}]}\end{array}$ & $\begin{array}{c}\mathbf{H i} \\
{[\mathbf{\%}]}\end{array}$ & $\begin{array}{c}\mathbf{N i} \\
{[\mathbf{\%}]}\end{array}$ & $\begin{array}{c}\mathbf{S i} \\
{[\mathbf{\%}]}\end{array}$ & $\begin{array}{c}\mathbf{O i} \\
{[\mathbf{\%}]}\end{array}$ & $\begin{array}{c}\mathbf{A i} \\
{[\mathbf{\%}]}\end{array}$ & $\begin{array}{c}\mathbf{W t} \\
{[\mathbf{\%}]}\end{array}$ \\
\hline Oil & 75.5 & 11.6 & 0.3 & 0 & 12.6 & 0 & 0 \\
\hline Meal (cake) & 51 & 7.4 & 4.7 & 0.3 & 23.117 & 6.686 & 6.797 \\
\hline Seeds & 58.9 & 8.6 & 3.7 & 0.3 & 20.045 & 4.193 & 4.262 \\
\hline
\end{tabular}




\subsection{Calorific power}

As can be seen from table 2, from calorific power point of view, camelina sativa subproducts can compete with conventional fuels. Because camelina sativa oil has a high calorific power value, it can easily be used as a superior fuel for industrial boilers, ships and even airplanes.

Table 2. Calorific power value for various fuels

\begin{tabular}{|l|c|}
\hline \multicolumn{1}{|c|}{ Fuels } & Calorific power [MJ/kg] \\
\hline Wood & $9-16$ \\
\hline Brown coal (Rovinari) & 9,80 \\
\hline Pit coal (Aninoasa) & 20,30 \\
\hline Camelina meal & 22,30 \\
\hline Methanol & 22,70 \\
\hline Pit coal (Vulcan) & 23,10 \\
\hline Camelina seeds & 26,60 \\
\hline Ethanol & 29,70 \\
\hline Camelina Oil & 36,20 \\
\hline Naphtha & 39,40 \\
\hline Diesel fuel & 44,80 \\
\hline
\end{tabular}

\subsection{Temperature variation inside the boiler and energy potential}

Our mathematical model allowed as calculating the following parameters:

- The volumes of air and combustion gases;

- The enthalpy of flue gases;

- The maximum theoretical temperature;

- The fuel flow;

- The temperature at the end of the furnace;

- The exhaust temperature.

Based on the fact that camelina cold oil has a high theoretical maximum temperature and requires a larger space for heat transfer by radiation, it is desirable to be used in big power station. In small boilers it is much better to burn meal and seeds as the exhaust temperature of the flue gases are lower, while the oil which has a higher energy potential can't transfer all the heat, and thus the temperature of the exhaust gases is bigger.

Table 3 present us the results of mathematical model simulation in terms of air and combustion gases volumes for all camelina sativa subproducts (seeds, meal and oil). The volumes of air and combustion gases are expressed in $\mathrm{m}^{3}{ }_{\mathrm{N}} / \mathrm{kg}$. In table 4 the values for combustion parameters resulted from our mathematical model are presented: the enthalpy of fuel gases, the maximum theoretical temperature, the fuel flow, the boiler efficiency, the temperature at the end of the furnace and the exhaust temperature.

Table 3. Results mathematical simulation - Volumes of air and combustion gases 


\begin{tabular}{|c|c|c|c|c|}
\hline $\begin{array}{c}\text { Volumes of air } \\
\text { and combustion } \\
\text { gases } \\
\end{array}$ & Unit & Camelina seeds & Camelina meal & Camelina Oil \\
\hline$V_{\text {Omin }}$ & {$\left[m_{N}^{3} / \mathbf{k g}\right]$} & 1,443 & 1,207 & 1,971 \\
\hline$V_{a 0}$ & {$\left[m_{N}^{3} / k\right]$} & 6,872 & 5,747 & 9,386 \\
\hline$V_{\text {awet0 }}$ & {$\left[m_{N}^{3} / k\right]$} & 6,982 & 5,839 & 9,537 \\
\hline$V_{\text {awet }}$ & {$\left[m_{N}^{3} / k\right]$} & 8,719 & 7,292 & 11,908 \\
\hline$V_{C O 2}$ & {$\left[m_{N}^{3} / k\right]$} & 1,1 & 0,952 & 1,41 \\
\hline$V_{S 02}$ & {$\left[m_{N}^{3} / k g\right]$} & $2,1 \times 10^{-3}$ & $2,1 \times 10^{-3}$ & 0 \\
\hline$V_{R O 2}$ & {$\left[m_{N}^{3} / k\right]$} & 1,102 & 0,954 & 1,41 \\
\hline$V_{N 2}$ & {$\left[m_{N}^{3} / k g\right]$} & 5,458 & 4,578 & 7,417 \\
\hline$V_{H 2 O}$ & {$\left[m_{N}^{3} / k g\right]$} & 1,127 & 1,006 & 1,45 \\
\hline$V_{0 g}$ & {$\left[m_{N}^{3} / \mathbf{k g}\right]$} & 7,687 & 6,538 & 10,277 \\
\hline$v_{g}$ & {$\left[m_{N}^{3} / k\right]$} & 9,408 & 7,977 & 12,629 \\
\hline
\end{tabular}

Table 4. Results mathematical simulation - Combustion parameters

\begin{tabular}{|c|c|c|c|c|}
\hline $\begin{array}{l}\text { Combustion } \\
\text { parameters }\end{array}$ & Unit & Camelina seeds & Camelina meal & Camelina Oil \\
\hline$h_{g}$ & {$\left[{ }^{\mathrm{kJ}} / \mathrm{kg}^{]}\right.$} & $1,442 \times 10^{4}$ & $1,229 \times 10^{4}$ & $1,923 \times 10^{4}$ \\
\hline$t_{t m}$ & {$\left[{ }^{\circ} \mathbf{C}\right]$} & $1,597 \times 10^{3}$ & $1,576 \times 10^{3}$ & $1,622 \times 10^{3}$ \\
\hline$\eta$ & [\%] & 78,773 & 78,583 & 78,993 \\
\hline$B$ & {$[\mathrm{~kg} / \mathrm{s}]$} & $2,664 \times 10^{-3}$ & $3,187 \times 10^{-3}$ & $1,953 \times 10^{-3}$ \\
\hline$t_{e f}$ & {$\left[{ }^{\circ} \mathbf{C}\right]$} & 644 & 642 & 647 \\
\hline$t_{\text {exhaust }}$ & {$\left[{ }^{\circ} \mathbf{C}\right]$} & 100 & 101 & 111 \\
\hline
\end{tabular}

As shown in figure 2, the highest temperature value is recorded in furnace, around 1600 ${ }^{\circ} \mathrm{C}$. In the furnace, the combustion gases are formed after the combustion process; and on their way to the evacuation the flue gases go through the pipes of smoke. The smoke pipes 
are introduced into a water tank, where part of the heat of the flue gas is transferred to the working agent and thus the temperature drops considerably.

Since the temperature of the flue gases at the exhaust is still high enough, $110{ }^{\circ} \mathrm{C}$, it is necessary to have two routes for the flue gases. In this case we must use a fan which means additional costs and high energy consumption. As can be seen from figure 3 , the highest velocity of the gases is at the end of the furnace.
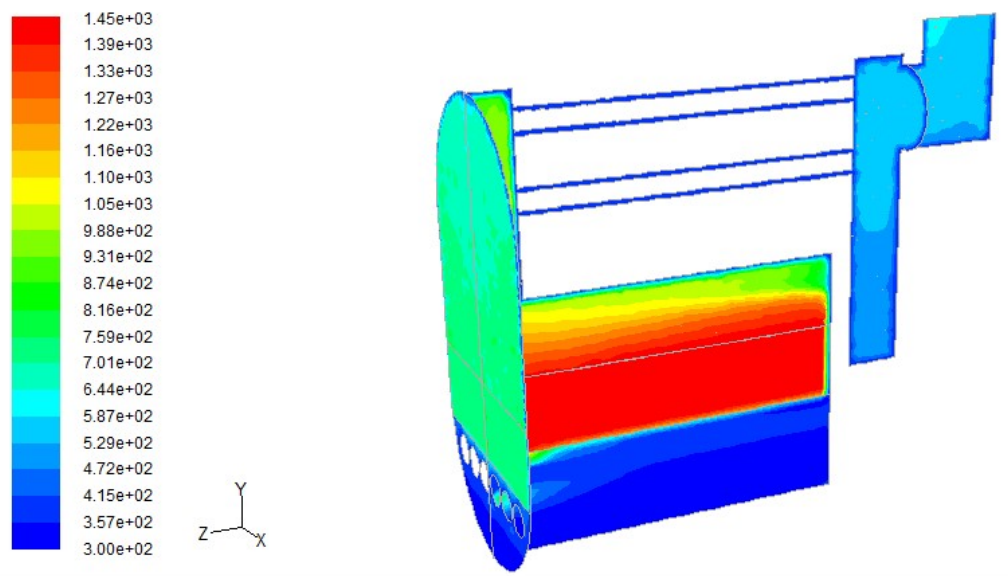

Contours of Static Temperature (k)

Fig. 2. Temperature variation inside the boiler
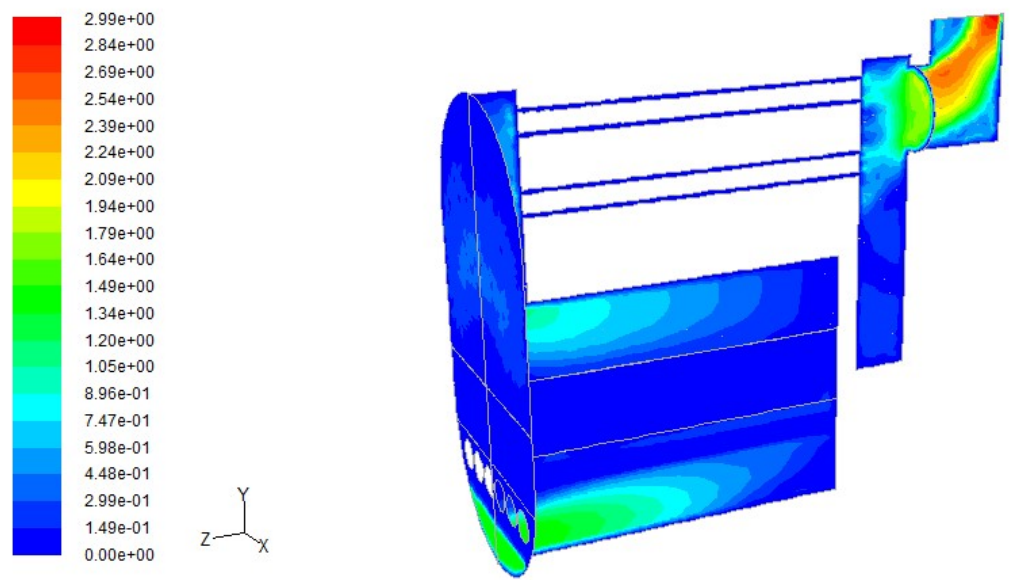

Contours of Velocity Magnitude $(\mathrm{m} / \mathrm{s})$

Fig. 3. Variation of gases velocity inside the boiler 


\subsection{Pollutant emissions}

From the point of view of polluting emissions, their values are not higher than other fuels; however, the use of chemical enhancers can lead to the appearance of harmful substances in the flue gases. The comparative analysis for all pollutant emissions for willow, acacia and camelina sativa biofuels (meal and seeds) is presented in table 5. Table 5 present also the air temperature and the

Table 5. Comparative analysis between the functioning of the boiler on willow, acacia, camelina sativa meal and seeds

\begin{tabular}{|c|c|c|c|c|}
\hline $\begin{array}{c}\text { Pollutant emissions } \\
\text { Temperatures }\end{array}$ & Willow & Acacia & $\begin{array}{c}\text { Camelina } \\
\text { meal }\end{array}$ & $\begin{array}{c}\text { Camelina } \\
\text { seeds }\end{array}$ \\
\hline $\mathbf{O 2}$ & $16 \%$ & $15 \%$ & $8.3 \%$ & $8.9 \%$ \\
\hline $\mathbf{C O}$ & $0.11 \%$ & $0.499 \%$ & $0.012 \%$ & $0.014 \%$ \\
\hline $\mathbf{C O 2}$ & $4.8 \%$ & $5.8 \%$ & $4.7 \%$ & $5.1 \%$ \\
\hline $\mathbf{S O 2}$ & $7 \mathrm{ppm}$ & $0 \mathrm{ppm}$ & $280 \mathrm{ppm}$ & $265 \mathrm{ppm}$ \\
\hline $\mathbf{N O}$ & $42 \mathrm{ppm}$ & $117 \mathrm{ppm}$ & $121 \mathrm{ppm}$ & $140 \mathrm{ppm}$ \\
\hline $\boldsymbol{\lambda}$ & 4.2 & 3.5 & 1.65 & 1.74 \\
\hline $\mathbf{T}$ air & $31.3{ }^{\circ} \mathrm{C}$ & $32.1^{\circ} \mathrm{C}$ & $29^{\circ} \mathrm{C}$ & $29.5{ }^{\circ} \mathrm{C}$ \\
\hline $\mathbf{T}$ gaze & $257{ }^{\circ} \mathrm{C}$ & $329^{\circ} \mathrm{C}$ & $251^{\circ} \mathrm{C}$ & $242{ }^{\circ} \mathrm{C}$ \\
\hline
\end{tabular}

\section{Conclusions}

Based on our results, Camelina sativa can be taken into consideration for replacing the conventional fuels in order to meet the 2030 targets with regards to biomass for energy production.

The calorific power values of Camelia main commercial products classify the Camelia seeds and meal besides Pit coal and Camelia cold oil between ethanol and fuel oil (naphtha).

The oil has the highest efficiency of use due to the conditions of the combustion process, mainly through the possibility of using excess air. Camelina oil should be used in big power station while camelina seeds and cake should be used in small power stations. Boiler efficiency calculated indirectly when using biofuels obtained from camelina sativa is around $78 \%$.

Since the main disadvantage of first-generation biofuels is that they come in direct competition with food, our future work will focus in obtaining camelina biomass for second generation biofuels and evaluate its perspective in terms of biofuels production and remediating the toxicity of soils.

This work has been funded by the European Social Fund from the Sectoral Operational Programme Human Capital 2014-2020, through the Financial Agreement with the title "Scholarships for entrepreneurial education among doctoral students and postdoctoral researchers (Be Antreprenor!)", Contract no. 51680/09.07.2019 - SMIS code: 124539. 


\section{References}

1. Ministerul Energiei, Strategia energetică a României 2019-2030, cu perspectiva anului 2050 (2019).

2. J.K. Crowley, EU Research Contract No. AIR3-CT 942178 (1995).

3. J.T. Budni, W.M. Breene, D.H. Putman. J. Am. Oil Chem. Soc. 72 (3), 309-315 (1995).

4. H. Prankl, K. Krammer, M. Worgetter, ALTENER Final Report, XVII/4.1030/Z/96013, 44-64 (1999).

5. S. W. Kruczynski, Energy Conversion and Management, 65, 1-6 (2013).

6. B. R. Moser, S. F. Vaughn, Bioresource Technology, 101, 646-653 (2010).

7. C. Ciubota-Rosie, J. R. Ruiz, M. J. Ramos, A. Perez, Fuel, 105, 572-577 (2013).

8. E. Corporan, T. Edwards L. Shafer, M. J. Dewitt, C. Klingshirn, Energy and Fuels, 25, 955-966 (2011).

9. A.G. Plessers, W.G. McGregor, R.B. Carson, W. Nakoneshny, Can. J. Plant Sci. 42, 452-459 (1962).

10. H. Abramovic , V. Abram, FoodTechnology and Biotechnology, 43, 63-70 (2005).

11. J. Zubr, B. Mattha"us, Industrial Crops and Products, 15, 155-162 (2002).

12. A.L. Pilgeram, D.C. Sands, D. Boss, N. Dale, D. Wichman, P. Lamb, C. Lu, R. Barrows, M. Kirkpatrick, B. Thompson, D.L. Johnson, , ASHS Press 129-131 (2007).

13. H. Schindlebauer, P. Hodl, Institute for Chemistry and Technology of Petroleum Products (Ed.), 9 (1994).

14. I. Toncea, D. Necsariu, T. Prisecaru, L. N. Balint, M. Ghilvacs, M. Popa, Romanian Biotechnological Letters, 5, 8594 - 8602 (2013).

15. I. Pîsa, C. Neaga, L. Mihaescu, T. Prisecaru, Generatoare de abur, Vol. I, Indrumar de laborator (Editura U.P.B., 1994).

16. C. C. Neaga, Tratat de generatoare de abur, vol I, ISBN 973-8130-67-0 (Editura AGIR, 2001).

17. C. C. Neaga, Cazane şi combustibili. Combustibilii energetici şi arderea (Centrul de multiplicare IPB, 1980).

18. C. C. Neaga, Determinarea randamentului unui cazan de abur în conformitate cu Recomandarea ISO (Energetica, 1976).

19. D. Stefanescu, A. Leca, L. Luca, A. Badea, M. Marinescu, Transfer de căldură şi masă (EDP, 983). 